\title{
Por que canta Anthony Seeger?
}

\author{
Clarice Cohn (Departamento de Ciências Sociais/UFSCar), \\ José Glebson Vieira (Departamento de Ciências Sociais/UERN), \\ Leandro Mahalem de Lima (mestre/PPGAS-USP), \\ Renato Sztutman (Departamento de Antropologia/USP) e \\ Rose Satiko Gitirana Hikiji (Departamento de Antropologia/USP)
}

Atualmente professor de etnomusicologia na University of California (UCLA, Los Angeles), o nova-iorquino Anthony Seeger (63 anos) dispóe de uma vasta e notável biografia, integralmente permeada por duas paixões: a antropologia social e a música. Oriundo de uma família repleta de músicos e compositores bem-sucedidos, Seeger, tocador de banjo, decidiu-se por estender a outra direção a paixão que herdou dos parentes. Optou pelas Ciências Sociais e, desde sua graduação em Harvard em 1967, vem realizando sua vocação com maestria. A etnologia ameríndia é a sua principal forma de arte.

Sua experiência como etnólogo está intimamente relacionada a seu trabalho de campo entre um grupo conhecido na literatura como Suyá, que hoje prefere ser chamado Kĩsêdjê, povo de língua jê, do Brasil Central (Parque Indígena do Xingu), realizado no início da década de 1970, durante sua pesquisa de doutorado (University of Chicago, concluído em 1974). Entre 1975 e 1982, Seeger foi pesquisador e professor no Programa de Pós-Graduação em Antropologia Social do Museu Nacional (PPGAS-MN-UFRJ, Rio de Janeiro). É preciso ressaltar também que o etnomusicólogo possui destacada atuação como diretor de arquivos audiovisuais. Entre 1982 e 1988 começou a exercer tal atividade 
como diretor do Archives of Traditional Music da Indiana University. E posteriormente, entre 1988 e 2000, dedicou-se integralmente à arquivologia como diretor e curador do selo Folkways do Smithsonian Institution, no qual produziu 250 discos e idealizou a recente página virtual de etnomusicologia Smithsonian Global Sound. Atualmente, ele é diretor do Ethnomusicology Archive na UCLA.

Seeger é autor de vários trabalhos sobre etnologia do Brasil Central, música ameríndia, etnomusicologia e direitos de propriedade intelectual. Dentre suas obras, destacam-se: Os indios e nós: estudos sobre sociedades tribais brasileiras (Campus, 1980); Nature and Society in Central Brazil: The Suya Indians of Mato Grosso (Harvard University Press, 1981); Why Suyá Sing: A Musical Anthropology of an Amazonian People (Cambridge University Press, 1987). Além disso, Seeger é editor de diversas coletâneas sobre arquivos, tais como a recente Archives for the Future: Global Perspectives on Audiovisual Archives in the 21st Century (Seagull Press, 2004), produzida em parceria com Shubha Chaudhuri. O currículo de Anthony Seeger pode ser acessado em http://www.ethnomusic. ucla.edu/people/seegercv.htm. Uma tradução de Why Suyá Sing, realizada por Guilherme Werlang, deve ser publicada em breve pela editora CosacNaify.

Em fins de novembro de 2007, Seeger esteve em São Paulo a convite do Instituto de Estudos Brasileiros da Universidade de São Paulo (IEBUSP) para participar do seminário Memória das Culturas, no qual apresentou, com humor e seriedade, a proposta de seu Smithsonian Global Sound. Aproveitamo-nos da ocasião. Seeger coordialmente concedeu esta entrevista, em português fluente, a Clarice Cohn, José Glebson Vieira, Leandro Mahalem de Lima, Renato Sztutman e Rose Satiko Hikiji. 
Revista de Antropologia, São Paulo, USP, 2007, v. 50 No 1.

Nós queremos começar ouvindo um pouco sobre sua experiência aqui no Brasil. Como foi sua chegada, sua trajetória, enfim, como foi sua história aqui no Brasil?

Cheguei ao Brasil por causa de Lévi-Strauss, de um lado, e por causa de Max Weber, de outro. Meu interesse era estudar relações entre organização social e cosmologia e também a música (arte). Eu estava estudando Antropologia em Chicago e poderia escolher qualquer parte do mundo. $\mathrm{Na}$ época eu não era um brasilianista e não sou ainda. E, com esse projeto, eu queria conhecer também as perspectivas de um grupo não capitalista. Eu achava que já havia muitos estudos sobre arte no capitalismo e muito poucos estudos sobre arte em sociedades não capitalistas. E para isso, evidentemente, precisava estudar um grupo isolado do sistema capitalista, porque mudava a organização social e cosmológica. Pensei na Nova Guiné, Austrália, Brasil e Peru... Procurei Stephen Hugh-Jones e ele me disse que o Xingu era mais viável para meus interesses de que o Alto Rio Negro. Também Terence Turner tinha conhecido um Kîsêdjê que havia passado pelas aldeias Gorotire (Kayapó) e sugeriu que eu poderia ir para lá. Só Amadeu Lanna (da USP) é que tinha passado por lá. Havia muito pouca coisa escrita sobre os Kĩsêdjê. Além disso, minha esposa havia realizado seu $\mathrm{PhD}$. em estudos de línguas latinas, especificamente o espanhol e o português. Então, o Brasil foi uma escolha óbvia, não porque eu gostava de samba e chope, nem porque estava dedicado a um grupo específico, mas por causa de um projeto de pesquisa. Quero salientar que minha mulher, Judith Seeger, me acompanhou o tempo todo no Brasil. Ela somente não está conosco hoje porque está lecionando nos Estados Unidos. Embora fale "eu" nesta entrevista, muito não teria acontecido sem a sua presença e senso de humor. Se não acreditam em mim, perguntem a Roberto DaMatta ou aos Kîsêdjê. 


\section{O senhor foi aluno de Terence Turner?}

Fui aluno de Terence Turner e de Victor Turner. Fui para Cornell, originalmente, para estudar com os dois - Victor por causa de sua análise do ritual, Terence por causa de seu intersse em sociedades Jê. No ano seguinte, os dois foram para Chigaco e eu os segui. Eu achava que os trabalhos de Victor sobre os símbolos e os sentidos da ação ritual eram muito importantes. Terence era muito jovem na época. Acredito que fui seu primeiro aluno na pós-graduação, mas foi ótimo professor.

\section{Mas o senhor já conhecia suas preocupações e os estudos jê??}

Sim, durante minha graduação, em Harvard, havia sido aluno de David Maybury-Lewis e li muito Lévi-Strauss com o Pierre Maranda. Eu e Roberto nos encontramos nos seminários de Victor Turner, que eram seminários abertos a todos. Acho que Victor modulou seu seminário seguindo seu professor, Max Gluckman, com base na proposta de Malinowski, professor de Gluckman. Era uma linhagem, uma maneira de abordar um assunto. Semanalmente nos encontrávamos na casa do Victor, a partir das oito horas até por volta de dez ou até meia-noite. A conversa começava com o trabalho de alguém. Às vezes, Victor lia o capítulo que estava escrevendo e depois parávamos para tomar cerveja. Se havia motivação, continuávamos com debates e entrávamos noite adentro. Era um seminário realmente deslumbrante. Era uma espécie de ritual de um grupo de etnografia. Havia alunos de pós-graduação e professores não somente de etnologia, mas também de estudos religiosos, professores visitantes e de diversos outros departamentos. Era magnífico.

\section{Como foi a recepção de Victor Turner ao material trazido do Brasil por você?}

Quando voltei do campo, em 1973, eu tive a sorte de receber uma bolsa para elaborar minha tese. Era muito difícil obter, só duas pessoas 
Revista de Antropologia, São Paulo, USP, 2007, v. 50 No 1.

conseguiram. Quando cheguei dos Kîsêdjê, Terence estava entre o campo e a Califórnia. Fiz o rascunho dos assuntos que iria cobrir nos primeiros seis meses e comecei a escrever meu trabalho. Escrevi, escrevi, escrevi - quatro páginas por dia, durante três meses - sem mostrar a ninguém, porque estava sem orientador para me cobrar. De repente, estava com quatrocentas páginas escritas. Primeiro contatei Terence, que voou da Califórnia para Chicago e ficou deitado no chão de meu apartamento lendo a tese durante uma noite toda. Ao final disse "tudo bem", saiu e pegou outro aviāo e nada mais. Quando Victor leu, ele disse: "sem problemas, mas acho que a descrição está muito regular. Será que realmente as coisas são assim, tão previsíveis? Porque, entre os Ndembu, eles dizem uma coisa, mas fazem outras; havia diferenças de opiniāo sobre coisas. Meus estudos me levaram a outras conclusões...”. E eu respondi que achava que sim, que de fato eram.

\section{E até hoje o senhor acha que são?}

Mais ou menos. Não estou dizendo que o que eles faziam era exatamente o que eles diziam, mas sim que o que eles diziam era bastante coerente e não tinham muitas diferenças de interpretação. Na época o grupo tinha aproximadamente setenta pessoas, e eles conversavam bastante entre si sobre o que eu estava investigando. Então, eu acho que era perfeitamente possível que eles entrassem em acordo. Era um grupo pequeno, e consistência em um grupo pequeno é algo que se pode esperar.

Fale-nos um pouco sobre a influência de Lévi-Strauss em seu trabalho.

$\mathrm{Na}$ época, Lévi-Strauss era muito lido. O ibope dele era muito alto tanto em Harvard quanto em Chicago, como em toda a Antropologia. Mas a parte da obra que me trouxe para o Brasil foi Tristes trópicos, os estudos sobre organização social jê e as Mythologiques. Quando eu estava escrevendo minha tese, eu descobri o quanto ele tinha percebido por 
meio dos mitos aquilo que eu estava descobrindo entre os Kîsêdjê. A importância dos sentidos... a lógica das qualidades sensíveis... essas coisas que ele bolou a partir daquilo que ele estava vendo por meio dos mitos.

Logo no inicio o senhor havia mencionado que seu interesse primordial já era a música e também todas as discussóes de Lévi-Strauss sobre o dualismo. E nós tínhamos uma pergunta exatamente sobre esse desenvolvimento do modelo jê, aqui no Brasil, para o qual o senhor ofereceu uma contribuição muito importante.

Antes de mim havia o Harvard Central Brasil Project. David Maybury-Lewis certamente foi importante na formação de alunos de graduação. Havia uma grande distância entre professores e alunos de graduação (como eu era) em Harvard. Os trabalhos dos antropólogos brasileiros tinham muita influência no trabalho do Harvard Central Brazil Project, mas só aprendi a ler português na pós-graduação. Foi um projeto muito interessante e tive sorte de poder participar de numa certa maneira.

Poderíamos dizer que o senhor é parte da segunda geração?

Poderíamos dizer, afinal de contas sou filho de filho; sou neto intelectual de Maybury-Lewis. Só que Terence Turner (para continuar a metáfora familiar) estava querendo até um certo ponto "matar o pai" por meio das fortes críticas a Maybury-Lewis. A idéia do grupo Jê era criar um espaço de compatibilidade, mas isso nunca aconteceu da maneira esperada.

E o senhor, em relação a Terence Turner, também queria matá-lo enquanto pai intelectual?

Não, eu não sou dessas coisas. Eu fiquei muito mais contente em não matar o pai, não precisava - trabalhamos sobre assuntos diferentes. 
Revista de Antropologia, São Paulo, USP, 2007, v. 50 No 1.

Aprendemos cantos um do outro em festas agradáveis na casa de Victor ou Terence (perguntem um dia sobre o repertório de cantos de Rugby que Terence possui).

Mas, de fato, suas contribuiçôes para esse debate rebatem exatamente nas coisas que estavam sendo feitas pelo grupo de Harvard e do Museu Nacional, não?

Sim, eu estava colocando meu trabalho dentro de um contexto que eu achava muito interessante que era o Projeto Jê. Eu li tudo antes e fiz meu projeto de tese em relação a isso, porque os Kĩsêdjê não tinham sido estudados pelo Projeto Jê. Eu achava interessante estudar uma área em que havia pessoas estudando outros grupos da língua da família linguística jê, que eram jovens e vivos ainda. Eu poderia indagar para eles aquilo que eles não escreveram. Todos eles tinham gravações e idéias sobre música, mas não escreveram sobre isso porque não achavam importante ou porque não se achavam preparados para a análise da música. Então, em parte, era uma situação que eu considero ideal.

\section{Como você chegou ao campo em 1971?}

Foi algo muito desastroso e difícil para um estrangeiro, para uma pessoa que não tinha parentes no país, com quem pudesse morar e que estava acompanhado de sua mulher. Chegamos ao Brasil em setembro 1970 (uma época difícil no Brasil). Fiz estágio no Museu Nacional com Roberto DaMatta, e enviei todos os papéis para entrar no campo. Após três meses de espera, acabou nosso dinheiro e fomos despejados. Estávamos alugando um quarto de uma pessoa que, de fato, não tinha direito a ter outras pessoas no apartamento. Era uma coisa desmedida. Fomos despejados porque o dono do apartamento queria receber mais dinheiro durante o carnaval. Felizmente, tínhamos uma carta de apresentação a uma família aqui em São Paulo - um amigo de um amigo do pai de 
minha mulher. Então, lhe apresentamos a carta, fomos convidados para um almoço de domingo e ficamos por quatro meses na casa. Sem essa gentileza de estranhos, eu acho que os Kísêdjê não teriam sido estudados por mim. Em São Paulo, morando aqui com eles, eu comecei estudando no Museu Paulista, e passei a pensar que poderia estudar um outro grupo Jê que não estivesse vivendo um problema de terras no Xingu. Então, eu pensei em fazer trabalhos com os Kaingang, aqui, enquanto estava esperando. Eu me encontrei com pessoas e grupos de antropólogos da USP que eram extremamente gentis. Gosto muito de São Paulo, tenho muitos amigos aqui. Em parte pela temporada forçada que tive de passar aqui, meu português melhorou bastante.

Afinal, uma noite estivemos em uma festa de antropólogos da USP na casa de Eunice [Durham]. Nós levamos nosso banjo e cantamos músicas folk de libertação em plena ditadura. Ruth Cardoso estava lá e posteriormente Fernando Henrique Cardoso chegou. Ele estava cassado na época e, então, alguém lhe disse: "Escuta, coitados desses americanos. Estão aqui há seis meses esperando a Funai e nada acontece. Será que você não conhece ninguém que possa ajudar?”. Ele disse: "Bom, eu tenho um professor que é diretor do Museu do Folclore no Rio de Janeiro, talvez ele possa ajudar...”. Escreveu uma carta, telefonou para seu amigo e nós fomos para o Rio e o visitamos. Então, o professor nos disse: "Ah sim, o ministro do Interior foi meu aluno na faculdade". Então, ele escreveu uma carta para o ministro, para solicitar a liberação do processo para o presidente da Funai. Então, a autorização saiu em duas semanas. O que me revelou muito sobre como, de fato, as coisas funcionam. Também, além disso, nesse momento, a estrada BR-080 tinha sido inaugurada e as terras do Parque desapropriadas.

Esta, então, foi mais uma situação na qual seu banjo foi um bilhete de entrada... 
Sem o banjo (e minha mulher com sua voz e capacidade de tocar violão) acho que estaria talvez trabalhando em alguma usina em algum lugarejo. Porque o banjo ajudou em todos os momentos - nas festas da universidade, na autorização para fazer pesquisa, e em nossas relações com a administração e grupos indígenas no Parque Indígena do Xingu. Nós, finalmente, chegamos ao campo com a ajuda das pessoas de São Paulo. Nós, o banjo e o violão. Na época era difícil viajar para lá. Só se chegava na região pela FAB. Só deixavam levar 60 quilos para minha esposa e eu, para os seis meses. A gente colocava miçangas nos bolsos, pesavam a gente antes de entrar no avião. Foram oito meses bastante complexos antes de chegar ao campo, mas, enfim, fiz muitas amizades.

\section{Como foi a chegada e a recepção dos Kî̃êdjê??}

Estávamos no avião com Cláudio Villas-Boas, mais duas ou três pessoas, e mais uma carcaça de um boi morto que cheirava mal. As cadeiras não eram para frente, eram cadeiras laterais de metal. O Cláudio nos levou para o Posto e pediu que a gente cantasse, e cantamos logo na primeira e na segunda noite.

\section{O que vocês cantaram?}

Cantamos coisas como: Oh, freedom, oh freedom, oh freedom over me. Before I'll be a slave I'll be buried in my grave... Cantos de direitos civis, como We Shall Overcome. Era possível cantar essas coisas no Xingu naquela época [1971] apesar da ditadura. Também cantei músicas africanas de três partes. As pessoas cantavam as primeiras, e eu cantava a última parte. Era muito divertido. Tínhamos um monte de cantos. O chefe Yawalapití disse: "Sabe que aquele posto tem sempre um gerador fazendo, Tum, Tum, Tum, Tum... Vocês não querem ir cantar na nossa aldeia?". Então nós fomos. No dia seguinte eles estavam preparando e iniciando o taruanã, e ele perguntou se eu não queria gravar e gravei. Então, 
quando acabou, eles disseram: "agora você canta para a gente". Então, nós ficamos sentados no pátio para cantar, e saiu um Yawalapití, ainda vestido de festa, com óculos escuros e um gravador Sony na mão, e ele gravou a gente. Então, foi ótimo e um indicador de que nós íamos ser estudados também.

\section{E os primeiros contatos com os Kî̀êdjê?}

Cláudio falou ao chefe dos Kîsêdjê: "Está chegando um casal de antropólogos americanos. Eles querem estudar sua língua e sua música. Eles vão escrever uma coisa e eu vou ler. Se você não gostar das pessoas, eles vão embora. Ensine-os bem". Os Kĩsêdjê me contaram isso seis meses depois. $\mathrm{Na}$ época, eles não queriam hospedar um antropólogo. Descobri isso recentemente pela Marcela Coelho de Souza, que agora está estudando os Kîsêdjê. Mas, depois de refletir, eles decidiram nos receber porque poderíamos representar alguma ajuda no futuro. Então, nos aceitaram.

O senhor acredita que a música foi importante nesse momento?

A música foi fundamental para a nossa aproximação, inclusive com o Cláudio Villas-Boas. As relações com ele em certos momentos foram difíceis, mas ele aturou a gente. Ele tocava violão...

Bem?

De fato, bem. Mas muito quieto e quase nunca em público. Subimos o rio com os Kĩsêdjê de canoa e chegamos à aldeia. Então, nos perguntaram se queríamos morar numa casa separada ou com alguém. Dissemos que achávamos que seria muito difícil morar sozinhos numa casa separada. Moramos na casa do chefe Kuiussi. Eles diziam o que o Cláudio dizia: "Eles são americanos. Os americanos são muito bravos. Eles jogam bombas. Estão jogando bombas em cima das pessoas no 
Revista de Antropologia, São Paulo, USP, 2007, v. 50 No 1.

Vietnã. Mas esse casal, essas duas pessoas gostam de música e vão cantar para vocês sempre que vocês pedirem". Então, cantar era, até certo ponto, uma obrigação.

Qual era a situação dos Kîsêdjê no Parque Indígena do Xingu naquele momento?

Eles estavam em um momento interessante. Porque quando Amadeu Lanna foi lá, ele descreveu os Kîsêdjê como sendo o único grupo altoxinguano que falava Jê. Entre mim e o Lanna, em torno de quarenta Tapayuna [outro grupo de língua jê], que sobreviveram à pacificação desastrosa no Rio Arinos, foram conduzidos ao Parque e alocados na aldeia dos Kîsêdjê. De repente, os Kîsêdjê fizeram uma nova aldeia redonda e começaram a cantar quase somente músicas jê. Eles estavam entre si conversando sobre os mitos, ritos, e suas maneiras de fazer e dizer coisas.

Queriamos voltar a algo que você disse: o fato de que eles conversavam sobre o que vocês estavam fazendo em campo. Isso é muito interessante. A reflexão dos indios sobre o conhecimento dos antropólogos. Eles tinham de falar as coisas certas, já que Cláudio iria avaliar depois. Mas eles também estavam refletindo sobre o "renascimento" que eles próprios estavam vivendo...

Os primeiros dias foram estranhos. Alguns homens falavam algumas palavras em português. Eles sempre checavam para saber se eu tinha entendido o que eles diziam, por causa de Cláudio. Mas depois deixou de haver essa insistência. Eu não falava Kĩsêdjê e não havia maneiras de aprender de antemão essa língua antes de chegar. Não havia estudos. Eles não aceitaram os missionários do Summer Institute of Linguistics (SIL). Eu tinha uma gramática kayapó, mas não era a mesma coisa. Os próprios Kîsêdjê diziam que só entendiam Kayapó se fizessem muito esforço. 


\section{E como o senhor conseguia se comunicar com eles?}

Tinha feito um curso de como aprender uma língua não escrita como aluno de pós-graduação em Chicago. Nos comunicamos inicialmente usando algumas palavras em português com aqueles Kîsêdjê que participaram de expedições de pacificação nas quais a língua franca era o português. Aos poucos os Kîsêdjê, com muita paciência, nos ensinaram a falar. Devemos muito a nossos professores.

E foi essa experiência do aprendizado da lingua que o levou a pensar as semelhanças do processo da etnografia com a experiência da criança?

Em parte, porque ali nós éramos totalmente crianças, embora eu tivesse 26 anos. Eu não falava, não enxergava (por exemplo, o pássaro tal na árvore grande). E a mesma coisa com o andar: não sabíamos andar nas matas ou no leito dos rios. Eles estavam sempre muito preocupados com a gente. Nós éramos realmente muito inocentes. Como meu domínio da língua era fraco, eu precisava investigar as coisas em ordem coisas presentes para depois falarmos de coisas abstratas. Então comecei com a roça. Plantamos uma roça, aprendi muito. Viajamos de canoa nos rios e aprendemos aspectos de lugares e espécies de animais, plantas e insetos. E depois foi o parentesco. Perguntava a todo mundo sobre parentesco. Em seguida, o ritual. Eles conversavam muito entre si sobre o que eu perguntava. Eu chegava ao centro do pátio e eles, às vezes, levantavam algo que eu havia esquecido de perguntar. E, de fato, ajudou muito trabalhar dessa maneira. Victor Turner não tinha muitas sugestôes sobre o trabalho de campo, apenas dizia: "você deve seguir o que é importante para eles". 
Revista de Antropologia, São Paulo, USP, 2007, v. 50 No 1.

\section{E, chegando para estudar música, como você chegou a um trabalho sobre natureza e cultura?}

Era mais fácil falar de roça, pesca, parentesco do que de mitos, rituais, ciclos de desenvolvimento doméstico (grupos de idade, crianças etc.)... Como é que se formula uma pergunta sobre metades? Eles não sabiam o que eram metades em português, e eu não sabia perguntar corretamente sobre coisas que não podia ver. A minha maneira de descobrir as coisas era ir ao pátio da aldeia à noite e ficar calado escutando. De vez em quando surgia uma palavra que eu não entendia, então escrevia na escuridão e no dia seguinte perguntava. Uma vez estávamos nos ornamentando para uma festa, e um Kîsêdjê disse: "Tem dois dançando lá no pátio". Eram aproximadamente 25, e eu lhe disse isso. E ele: "Só tem dois. Sempre quando estamos colocando ornamentos de braço dizemos 'onde está o outro como este?' Sempre temos um e outro". "Os dois" dançando eram as duas metades. Eram 25, mas eram dois de fato. Essa foi a observação-chave que me levou a descobrir como se falava sobre metades. Com os cantos, foi a mesma coisa. Como é que se pergunta "como se estrutura sua música?". Perguntei, perguntei... Como são os esteios centrais da música? Meu melhor informante dizia: "Não sei o que você quer dizer... Casa tem esteio, mas música não". Foi somente mais para o final que escutei uma pessoa falando para outra: "Você esqueceu o sindó daquela coisa...". Eu perguntei o que era isso. E descobri que todo canto tem duas partes, uma chamada sindó e a outra kradi, que são como leste e oeste. E de repente descobri que os cantos, na visão deles, têm a mesma estrutura que o espaço e as metades. Então, descobri exatamente o que eu estava investigando: havia uma sobreposição de estruturas de relações sociais (de cosmologia e de espaço-tempo) e de música. Mas música é uma coisa difícil de conversar, pois todas as sociedades do mundo se referem a ela usando metáfora. 


\section{Havia uma estrutura dual na música...}

Inteiramente dual. Mas não somente isso. Havia cantos individuais chamados akia. Quando uma pessoa canta, ela canta de acordo com sua idade. Então, o canto de uma pessoa muda ao longo da vida. O canto de uma criança tem somente uma parte. Quando chega a aproximadamente 10 anos, de repente, passa a cantar em duas partes. Depois, três partes. A pessoa canta muito alto quando jovem, médio-alto quando tem filhos e depois não canta mais quando tem netos. Existe um grito especial para os velhos. Então, os sons eram todos ornados de um lado com coisas fixas e de outro mudavam conforme a posição pessoal nesse sistema. Eu chamava a sociedade de "uma orquestra," mas os "instrumentos" eram pessoas de idades e gêneros diferentes que se representavam por meio de seu canto.

\section{O mesmo pode ser dito da oratória masculina?}

A fala sim, pois só homens adultos desempenhavam a oratória. Os mais jovens falavam de uma certa maneira e raramente falavam em certos lugares. Os mais velhos falavam em certos lugares. As mulheres também têm vários tipos de falar, dependendo da formalidade da ocasião. Quando eu fui ao campo em 1971, não tinha velhos, porque tinham morrido todos. Eu cheguei a uma aldeia em que o mais velho era aproximadamente dez anos mais velho do que eu. Então, não tinha homens velhos. Por isso não sei se os velhos não falavam. Eu sei que os muitos velhos Tapayuna não falavam.

Entre os Kayapó, os mais velhos se retiram da cena imediata... Poderia ser... É consistente. 
Mais alto significa mais forte ou mais agudo?

Mais agudo e também mais forte. Eles não se preocupam com tom fixo, porque não tocam flauta sistematicamente e não escrevem música. Então, os mais jovens deveriam ser aqueles que cantam mais alto (em amplitude) e mais agudo (em tom).

\section{O senhor aprendeu a cantar em Kïsêdjê?}

Claro. Eles disseram que entre seus cativos eu era o melhor cantador.

Em que momento o senhor começou a cantar com eles?

No primeiro ritual que eles fizeram, perguntaram se eu queria cantar com eles. Eu disse que sim. E eles disseram que eu não ia conseguir aprender os cantos individuais. Eu falei que talvez pudesse aprender. Eu gravei, fiz uma transcrição e, no dia seguinte, estava cantando. Foi a primeira vez que os jovens acharam interessante aprender a escrever. Porque assim poderiam aprender mais rapidamente as canções.

Sua primeira canção foi como jovem ou como homem maduro?

Como jovem. Meu primeiro canto tinha duas partes, mas eram relativamente curtas e fácil de lembrar. [Começa a cantar o trecho.]

\section{Este canto é unissono?}

Não, cada pessoa tem um canto tipo akia diferente. Então, quando tem 25 pessoas cantando são 25 cantos diferentes. Cada melodia é diferente. Isso é polifonia. Tem muito mais vozes diferentes do que Bach escreveu. Eu chamei meu livro Por que Cantam os Suyá? (Why Suyá Sing?) por não entender porque todos gritavam coisas diferentes. Era um som tão estranho... muito diferente de tudo o que eu já tinha ouvido. 
O senhor diz em um de seus artigos que a oratória é falada, o mito é contado, a canção é cantada, mas que todos são música para seus ouvidos... Gostariamos que falasse um pouco mais sobre isso.

Eu achava que a distinção entre fala e música (especialmente quando a música é toda cantos e, por consequiência, palavras) era uma coisa problemática. $\mathrm{Na}$ fala se usam tons e também se manipula o tempo; na música se usam tons e se manipula o tempo. Então, eu achava que, em vez de dizer que esta é música e aquela é fala, existe a maneira de se manipular os tons e os tempos na fala cotidiana - assim como aqui conversando em volta de uma mesa, que é diferente da maneira de usar a fala ritual (mais recitativa como uma ópera) -, que era diferente da oratória para um público, que era também diferente dos cantos. Mas todos têm esses aspectos de tons, palavras e tempos. Acho que é uma questão de quais são os parâmetros em que se muda de um para o outro. Eu estava tentando evitar falar exclusivamente "na música", minha intenção era mostrar o leque amplo que existia no desempenho oral.

É possivel fazer etnomusicologia sem ser músico?

Eu acho que sim. Depende da análise que se pretende fazer do desempenho musical. Certos tipos de análise requerem formação musical, outros não.

Você acha que um não-músico, ou alguém que não tivesse uma relação profunda com a música, que chegasse aos Kïsêdjê teria a percepção da importância da experiência musical tal qual o senhor descreve?

Eu acho que não, porque eu acho que não lhe interessaria. Tem muitos estudos sobre os rituais jê e muitas referências ao fato de que eles cantam, mas ninguém tinha se aprofundado nos sons da música.

Em Nature and Society, baseado em minha tese de doutorado, eu não escrevi sobre música porque ainda não entendia. Primeiro porque o tra- 
balho já tinha 400 páginas. E também porque eu estava preocupado com as relações entre cosmologia, organização social e música, e acabei ficando em cosmologia e organização social. Eu não entendia o suficiente sobre música. Acabei deixando a música para um estudo posterior, depois de já dominar melhor a língua.

E como foi a vinda para o Museu Nacional depois de escrever a tese?

As relações pessoais são muito importantes em tudo no Brasil - não apenas no Brasil, mas em todo lugar... Cheguei em 1970 e saí no final de minha pesquisa de doutrado em 1973. Na saída do campo, em março de 1973, Roberto DaMatta me perguntou: "Você quer dar um curso comigo sobre parentesco? Vai ser divertido...”. Eu não tinha nada a perder, não precisava chegar a Chicago tão cedo, tinha coisas que eu queria analisar nos meus dados antes de partir, então respondi que sim. Então, ele arranjou uns 3.000 dólares, o suficiente para eu alugar um apartamento e dar aula uma vez por semana. E trabalhamos muito bem juntos. Ele com saltos imaginativos muito grandes, e eu: "Bem, mas vamos ver o que o Morgan dizia...”. Foi muito divertido. Eu fiz amizade com todos os professores na época. Fizemos festas, e eu cantei. Depois voltei para Chicago, escrevi minha tese, consegui um emprego e perdi o contato constante com o Brasil. Na Califórnia, de repente, eu recebi um telefonema de Roberto DaMatta. Ele me perguntou: "Tony, você quer voltar para o Brasil? Eu tenho cinco vagas que a Universidade me deu, porque Roberto Cardoso saiu, Melatti saiu... Tem Moacir, tem Lygia, tem Otávio, tem Gilberto, mas não tem ninguém da Etnologia, e nós achamos que você seria ideal porque você é a única pessoa que nós conhecemos que fala a língua e que poderia tratar da área indígena com seriedade. Você realmente passou um tempo estudando e aprendendo a língua...". E eu falei: "Espere que daqui uns dias eu the telefono de volta”. Então eu telefonei para Terence Turner, e ele disse: "Eu acho que 
você não deve ir. Você sabe que de vez em quando, no Brasil, parece que vai ter coisas que não acontecem e você vai jogar este emprego fora, vai chegar lá e vai se perguntar 'será que vou ter mesmo este emprego'?". Perguntei então a Victor Turner: "Ah. Eu acho que você não deve ir. Eu tenho alguns colegas meus de faculdade, alunos de Gluckman, que foram para a África e sumiram, ficaram envolvidos em coisas por lá, mas pararam de participar da antropologia internacional". Perguntei a David Schneider: "Você não deve ir. Você está com um excelente emprego, um bom lugar, por que você quer sair?”. Apesar de todos os conselhos, eu aceitei o convite de ir ao Museu Nacional. Mas eu vim para o Brasil em parte porque já sabia o que ia encontrar no Museu Nacional e confiava em Roberto. E também tinha a intenção de não me perder da antropologia internacional, poupando dinheiro para ir a congressos internacionais todos os anos em período de férias. Eu vim já avisado dos problemas, mas certo de que seria interessante porque poderia fazer mais pesquisa de campo, poderia tomar chope gelado e, além disso, minha mulher estava interessada em fazer uma tese sobre o romanceiro no Brasil e poderia fazer seu trabalho durante esse tempo.

Uma das coisas interessantes de sua obra é que ela tenta dar uma resposta um pouco diferente ao modelo do dualismo jê e bororo, tal como foi proposto por Maybury-Lewis...

Agora vocês estão iniciando uma conversa sobre trabalhos que escrevi há décadas. É bem provável que vocês saibam melhor o que escrevi naquela época de que eu. Meus trabalhos mais recentes são sobre a música, mas vou tentar responder.

Eu estava partindo de minha pesquisa junto aos Kîsêdjê, e, se havia congruências com Lévi-Strauss e outros autores, era porque eu tinha observado e ouvido isso dos Kîsêdjê. Esse era o ponto de partida de minha etnografia. Eu estava falando com esses outros autores. Sobre o dualis- 
Revista de Antropologia, São Paulo, USP, 2007, v. 50 No 1.

mo, parecia realmente que, quando havia um, você poderia procurar em todos os níveis um outro - tudo vinha em pares. Em outras palavras, tudo o que eu digo em 400 páginas pode ser reduzido a uma observação dos Kîsêdjê. Quando falávamos sobre Natureza e Cultura, eles insistiam que eu conhecesse a todos os aspectos da vida. Eu não poderia ficar na aldeia de braços cruzados. E outra coisa é que havia uma relação das coisas da natureza, de fato, que atuavam sobre a vida social. Não era uma coisa de oposição rígida, um lá e outro cá. Obviamente tem uma grande troca entre um e outro, de vários tipos de relação, de comida, de pensar, de cantos...

A própria idéia de que os animais entoam os cantos é interessante para pensar a relação entre natureza e cultura entre os Jê.

Sim. Eu acho que em Why Suyá Sing?, especialmente, se torna menos rígido nesse aspecto. As categorias de espaço são mais rígidas...

Um outro etnomusicólogo, Steven Feld, fala que o canto dos pássaros entre os Kaluli da Papua-Nova Guiné é música, e os ocidentais estabelecem essa divisão em que a música é fruto da agência humana. E nessa cosmologia não, a natureza também produziria música...

Sim. No perspectivismo, em que os animais se pensam humanos, mas os Kîsêdjê pensavam os animais como sociais também. Os Kîsêdjê foram lá para as aldeais diferentes de espécies animais ou vegetais, ou seus espíritos foram para a aldeia, aí estavam todos cantando. Lá, os Kîsêdjê aprenderam as canções e trouxeram. Quando estavam cantando, estavam cantando na aldeia música de animais e peixes e vegetais. Eles não modelaram seus cantos nos pássaros cantando nas árvores, mas nos pássaros cantando juntos em sua própria aldeia. Feld, sobre os Kaluli, fala dos pássaros de fato, que você pode gravar lá. Os Kîsêdjê dizem que os cantos dos pássaros são cantos dos pássaros em suas aldeias, dos peixes 
em suas aldeias. É muito diferente nesse sentido. Mas o Steve e eu somos fâs um do outro.

Como o senhor vê os temas do animismo e do perspectivismo em um grupo Jê?

Não sei. Eu dirigi uma companhia de discos durante 12 anos. Minhas voltas para os Kĩsêdjê desde 1994 têm sido muito mais no sentido de amizade, curiosidade e assistência. Não posso falar como o perspectivismo funciona para os Jê porque realmente não tentei aplicar entre os Kísêdjê. Acredito que tem coisas profundas aí que poderiam me ajudar a repensar coisas perdidas que tenho em minhas anotaçōes. Mas, para responder mais que de forma anedótica sobre esse tema, teria de rever com seriedade meus cadernos de campo.

O perspectivismo é muito pensado a partir de metáforas visuais. Poderia ser pensado também por meio da música, de metáforas musicais?

Podemos falar dos animais ouvindo os homens cantar? Não conheço um caso de mito em que um animal aprendeu um canto de um ser humano.

O exemplo dos pássaros é um exemplo propriamente perspectivista. Porque não é o canto do pássaro que é música, mas o canto dos pássaros em sua agência humana, entre eles se vendo como humanos.

Sim. Mas eu não tenho pensado sistematicamente sobre a questão.

O senhor poderia falar um pouco sobre a redação do artigo "A construção da pessoa...", em conjunto com DaMatta e Viveiros de Castro?

$\mathrm{Eu}$ acho que esse texto saiu em parte dos dados kisêdjê e apinajé, e do trabalho que citamos, African Models in the New Guinea Highlands, de Barnes. Não há linhagens "clássicas” (tipo Grego ou Romano ou 
Nuer) entre os Jê e, se elas existem ali, certamente não são tão importantes e consistentes como em partes da África. Então, a única coisa que dava para generalizar era o corpo. O corpo era obviamente importante: era o principal objeto de desenhos, e as idéias de crescimento e socialização do corpo eram amplamente espalhadas na literatura etnográfica sobre a América do Sul. A visão do antropólogo geralmente começa com leituras, depois passa para a experiência de campo e posteriormente pela reflexão sobre assuntos diante de outras leituras. Fizemos esse trabalho a seis mãos, o que foi complicado mas funcionou. Convidamos colegas para uma reunião no Museu Nacional e achamos que estávamos encontrando uma maneira de começar a pensar comparativamente a América do Sul.

Como suas reflexóes sobre corpo e pessoa se articulam a temas como performance e drama? Estamos pensando aqui na influência de Victor Turner em sua obra.

Victor também gostava de música, dançava e cantava cantos ndembu. Desde o início me interessei por trabalhar com música e performance. Trabalhava com música e me interessava por performance. Para mim era um tema óbvio. Tem aspectos da antropologia que não procuram ver como as pessoas estão, de fato, encarnando e fazendo as coisas; muitos antropólogos são presos a fala e categorias. Mas em música e ritual o importante é o desempenho, que faz que as coisas aconteçam. O processo de fazer é a coisa importante. Isso me leva diretamente para a performance e o que ela significava. Veio em parte de Victor Turner, em parte no estudo de desempenho de falar, e em parte realmente porque estava estudando música. Quando falo em Antropologia Musical em Why Suyá Sing? é porque eu achava que o estudo da música, a atenção ao desempenho e a atenção às coisas acontecendo no momento da ação poderiam trazer coisas boas para a Antropologia. Eu escrevi isso em 1987 
quando a antropologia era um pouco mais rígida, agora ela já incorporou essas idéias de processo.

Isso foi bem recebido por Victor Turner?

Não sei. Eu não o encontrei tanto quando eu estava morando aqui e ele em Virginia. Nos víamos de passagem em reuniōes da American Anthropological Association. Ele veio ao Brasil um ano para passar o Carnaval e ficamos fazendo um "swiminar" na piscina de Roberto DaMatta. Passamos horas e horas na piscina durante o dia trocando idéias sobre tudo, depois festejamos à noite. Mas não tocamos nesse assunto, trocamos mais idéias sobre Carnaval, música, communitas, a vida, coisas assim...

Qual o lugar da música na proposta antropológica de uma melhor compreensão acerca do Homem?

Boa pergunta. Não sei se tenho uma resposta direta. Vamos ver... [silêncio]. Se você olhar para o tempo que as pessoas jê passam cantando e o tempo que precisavam usar para caçar ou pescar, a música tomava muito tempo, muita atenção e muitos recursos. Deveria ter algo muito importante para eles na música e no ritual. Se não, por que fariam? E também os Kîsêdjê sempre apontavam para a música e achavam que esses cantos eram muito importantes para eles. Eles cantavam os cantos de seis grupos indígenas diferentes, um canto em francês que eles aprenderam com os Trumai, muitos cantos em inglês que eles aprenderam com a gente. Para eles o canto era fascinante. Quando passava um visitante na aldeia, eles chamavam à noite para o pátio e insistiam que cantasse, canto após canto após canto... Os Kayapó faziam a mesma coisa quando eu passava por lá.

O canto foi também importante como uma relação com o mundo. E, se os Araweté e os Tupi em geral têm uma certa relação com o outro, 
Revista de Antropologia, São Paulo, USP, 2007, v. 50 No 1.

de aproveitar para seu próprio grupo do ser do outro, eu acho que os Kîsêdjê estavam fazendo uma maneira de se relacionar com as pessoas por meio da aprendizagem e desempenho da música. Eles não adotaram os nomes dos inimigos, mas sim adotaram as músicas dos inimigos.

A música não é importante igualmente em todas as sociedades. Todas sociedades têm estruturas de sons que são claramente distintas das estruturas de comunicação. Mais redundantes, as estruturas de sons são mais regularizadas e repetidas. Mas isso não quer dizer que a importância da música para os Jê seja necessariamente igual para os Suni no Iraque. De fato, em certas práticas do Islã, a música é considerada um mal.

\section{Mas o canto é uma coisa fundamental na liturgia do Islã, não?}

No Islã, quando eles fazem a oração, dizem que não é música (embora soe musicalmente). É um discurso, um sermão. É tudo música para meus ouvidos. Mas para eles é diferente. A recitação do Qran geralmente não usa instrumentos musicais. São os instrumentos que fazem e levam à dança e a relações impróprias entre as pessoas. Há uma repressão muito forte por parte do Taleban com relação à música. Mas eu acho que entre os Kîsêdjê, entre os indígenas do Brasil, e propriamente das Américas, a música é realmente uma parte importante da vida, da maneira de se construir como indivíduos e pessoas, da maneira de se construir como grupos e da maneira de se relacionar com os outros grupos. Posso falar sobre um projeto que não fiz ainda?

\section{Claro. Adoraremos ouvir.}

Há muito tempo eu queria fazer uma pesquisa comparativa com os grupos Jê sobre música, especialmente Apinajé, Kayapó e Timbira. Entre eles há uma semelhança de cosmologia, de ritos, de nomes e de organização social. Tudo isso é muito consistente. A questão é: e a música? Se essa relação entre música, a cosmologia e o espaço-tempo que encon- 
trei entre os Kĩsêdjê é presente nos outros... Porque se for presente nos outros é uma coisa interessante e amplia minha análise. Se não for, então será que os Kĩsêdjê e eu inventamos os princípios que descrevo operando em sua música sozinhos? Eu escrevi Why Suyá Sing? para mostrar as possíveis relações entre cosmologia, organização social e a música, mas será que eu, querendo ver essas coisas, as inventei com um grupo pequeno que era de fato muito simpático nos ajudando com a pesquisa? Eu ganhei duas bolsas para pensar isso em 1988, mas eu fui contratado pelo Smithsonian Institute, então larguei a pesquisa. Mas estou começando a fazer isso agora. Eu fui em maio de 2007 para Carolina, no Maranhão, para visitar o arquivo de músicas timbira. $\mathrm{O}$ meu primeiro projeto era ir para as terras de todos os antropólogos que fizeram pesquisas com os grupos jê, ficar em suas casas, tomar cerveja, fazer cópias de todas as suas gravaçóes, anotar coisas que eles poderiam dizer e depois fazer a pesquisa comparativa. Mas agora, com o surgimento dos arquivos propriamente indígenas, é mais interessante. As gravações não são perfeitas, mas foram feitas por pessoas que realmente entendem a música que estão gravando. Podem ser mais completas e mais cuidadosamente escolhidas.

Gostaríamos que o senhor falasse um pouco sobre a proposta e concepção do Smithsonian Global Sound.

Primeiro deixe-me falar um pouco sobre os arquivos multimídia, porque eu acho que a preservação de música é importante em si. Enquanto aluno de pós-graduação, já conhecia o arquivo de Indiana e já coloquei cópias de minhas gravações dos Kĩsêdjê imediatamente depois de voltar do campo, para a salvaguarda. Quando eu estava gravando com os Kîsêdjê, falei para eles: "um dia talvez seus bisnetos vão querer ouvir estas suas músicas. Eles podem ir para o arquivo de Indiana sempre que quiserem, que elas vão estar lá”. Eles ficaram contentes, mas era um 
Revista de Antropologia, São Paulo, USP, 2007, v. 50 No 1.

outro planeta. Posteriormente, quando eu saí do Brasil em 1988, fui para Indiana dar aula de Etnomusicologia e Antropologia e fui convidado para ser diretor do Arquivo onde estavam minhas gravações. Mas eu fui avisado por meu chefe: "A administração está convidando você para ser diretor porque você tem permanência no departamento, mas eu acho que eles vão fechar o arquivo". Então pensei: "Será que devemos fechar o arquivo, usar o espaço para produção musical e dança, e usar o dinheiro que estávamos usando para preservar os materiais para a produção de novos materiais?”. Me dei três meses para resolver a questão: realocar o arquivo na biblioteca ou mantê-lo aberto. Eu estava lendo Marx para dar uma aula, o 18 Brumário... Não sei se vocês se lembram, mas o primeiro parágrafo é fantástico. Entre as coisas que ele disse, foi mais ou menos: "exatamente quando as pessoas, os seres humanos estão em momentos de fazer mudanças profundas em suas sociedades, em suas vidas, eles buscam o passado e pegam os seus velhos gritos de guerra, as velhas maneiras de se vestir...". Marx criticou essa tendência como um dos motivos pelos quais fracassou a revolução de 1848 . Eu, mais de cem anos depois, perguntei: será que isso é verdade? Pode ser que de fato as pessoas buscam o passado em momentos de profundas transformaçōes sociais, nos momentos em que estão criando seu próprio futuro. Se isso for verdade, então os arquivos não são repositórios de coisas velhas que ninguém quer mais, são repositórios de ferramentas de construção do futuro. Com essa perspectiva sobre os arquivos, eu passei a achar que os arquivos tinham validade e que eu deveria argumentar não somente para não fechar, mas para ampliar. E depois entrar em uma política para a qual essas ferramentas fossem conhecidas pelos grupos que estavam querendo usar no momento certo. Foi por isso que eu virei um arquivista.

As vozes que estão em arquivos não são as vozes dos vitoriosos, incluem as vozes dos vencidos, dos oprimidos, das pessoas que não sabem escrever. Os antropólogos e etnomusicólogos trabalham muito mais fre- 
qüentemente com oprimidos do que com opressores. $\mathrm{O}$ arquivo na Indiana University estava cheio de vozes, que eram as vozes de pessoas que estavam falando com etnomusicólogos, antropólogos, que estavam falando de coisas que não falariam se tivessem sido gravadas por outras pessoas. E muitas coisas que estavam lá que poderiam ser úteis não estavam em outras fontes, não estavam nos livros dos vencedores e não estavam nos livros dos antropólogos que utilizaram somente uma parte das entrevistas. Então, por isso, passei seis anos lá.

A frustração do arquivista é que você tem o material, mas não tem direito de divulgar - em parte pelas leis de propriedade intelectual, em parte pelas restrições do doador, do pesquisador... Quando recebi a oferta de dirigir um selo de discos que era famoso por ter muitas músicas de Etnologia do mundo todo, de sons que são muito esquisitos, mas interessantes - um disco inteiro sobre sons de râs norte-americanas, por exemplo -, eu achei ideal porque lá eu estava em posição de, em vez de ter problemas de distribuir, fazer quantas cópias fossem possíveis e mandar para o mundo. Aceitei.

Eles foram muito gentis. Eles disseram que eu poderia fazer qualquer coisa que eu quisesse, menos perder dinheiro. Mas eles só me deram 17.000 dólares para operacionalizar a coisa - uma miséria. Uma companhia de discos funciona com milhões de dólares. Então foi um desafio muito grande. Produzimos mais ou menos vinte discos por ano, mantivemos dois mil cento e tantos outros que já existiam, e estavávamos captando outras companhias de discos para adicionar ao acervo materiais que poderiam ser distribuídos. Após 12 anos, voltei a dar aulas. Passei de 1988 a 2000 no Smithsonian. Aprendi e me diverti muito, especialmente quando estava montando alguma coisa nova. Manter é um pouco chato, você tem sempre de pensar sobre dinheiro no final do ano, tem sempre de reclamar dos antropólogos que não sabem escrever enxuto, que escrevem textos tão longos que não cabem nos CDs. Depois 
Revista de Antropologia, São Paulo, USP, 2007, v. 50 No 1.

de um certo número de anos, estava ficando mais como um trabalho que como uma diversão. Estávamos vendendo cerca de 200 mil cópias por ano, e em cada uma tinha algo que eu havia feito. Ou era o editor ou escrevia a apresentação. Eu estava presente em milhares de lugares. Foi realmente liberador no sentido de atingir o grande público. É claro que o grande público não era tão grande assim em comparação com a Sony, por exemplo. Mas eu estava atingindo um grande número de pessoas com minhas idéias e meu trabalho.

O Global Sound tem como base três atores fundamentais: o arquivista, o coletor e o artista. Propõe uma relação autêntica entre essas partes. Como funciona a captação e transferência de recursos entre o arquivista, o coletor e o artista no projeto do Global Sound?

O Global Sound começa com quatro pontos iniciais. Primeiro, achava que as artes tradicionais, nas aldeias indígenas e no mundo todo, estavam sendo afetadas pela falta de pessoas para aprender dos velhos. E isso estava acontecendo em parte porque só a arte nova tinha proteção e dinheiro. A arte popular, a arte nova tinham copyright. Conhecimento "tradicional e folclore" em muitos países são excluídos de copyright. Então eu queria criar um sistema de distribuição em que uma parte do dinheiro ganho fosse diretamente para os artistas. Assim, eles ganhariam não apenas uma soma em dinheiro, mas também prestígio. Com dinheiro e prestígio em jogo, jovens poderiam talvez começar a estudar com os mestres.

\section{$O$ dinheiro é ganho individualmente?}

Em princípio individualmente. Varia de caso a caso. Mas indivíduo ou grupo, até se for para grupo todo, confirma a importância do que você está fazendo. E talvez dê pra comprar 1 litro de gasolina, enfim, uma coisa pequena. 
O segundo ponto era que os arquivos no mundo todo são mal financiados e têm problemas de prestígio porque as pessoas pensam que são repositórios de coisas que ninguém quer mais, ao invés de pensar que são uma maneira de construir o futuro. Dinheiro para os arquivos traria também prestígio.

E terceiro é que eu achava que havia muita gente no mundo todo que estaria interessada nesses materiais oriundos de arquvios, materiais estes que não eram gravados para publicação. Não eram cortados para caber em discos, mas eram feitos de pesquisa. E a melhor maneira de fazer esse tipo de difusão seria pela Internet.

Finalmente eu achava que poderia criar um espaço na Internet que não seria apenas para os arquivos sonoros digitais, que são fáceis de fazer e transmitir, mas que incluiria informações e textos que faltavam na maioria das maneiras de organizar música na Internet. Criamos o Global Sound para isso. A idéia era criar uma rede de arquivos do mundo todo - cada arquivo colocaria na Internet uma parte da coleção sobre a qual ele detinha os direitos - e poderíamos colocar as músicas do Smithsonian. A intenção era cobrar pelos downloads. Metade do dinheiro recebido ficaria com o Smithsonian para juntar novos arquivos ao projeto e pagar o preço de manter o site. E a outra metade ia para os arquivos e eles deveriam pagar a metade do que recebiam para os artistas dos itens que foram baixados. A realização desse projeto foi complicada. Demorou anos para lançar o sítio. Mas está funcionando finalmente. Além de poder comprar faixas individuais e ver toda documentação, as universidades e escolas podem licenciar o acesso para todos os alunos de todo o material. O material escrito sobre o som é de graça, a única coisa que se paga é a música. 
Revista de Antropologia, São Paulo, USP, 2007, v. 50 No 1.

\section{E o projeto se auto-sustenta?}

Ele se auto-sustenta, mas para iniciar recebemos financiamento da Rockafeller Foundation.

Gostaríamos que falasse rapidamente de sua posição como artista.

Como artista eu tive meu pico aos 18 anos. Durou até os 20. Como aluno de graduação em Harvard eu realmente não me liguei muito aos estudos, mas me diverti. No terceiro ano, de repente estava trabalhando muito como aluno e decidi que precisava diminuir a música - não parar de tocar, mas de tocar seriamente, de pensar em ser músico. Um tio meu, Mike Seeger, passou por Boston fazendo um show com seu grupo, The New Lost City Ramblers. Eles estavam no final de uma longa turnê, estavam num bar cheio de fumaça e ninguém estava prestando atenção na música deles. Depois jantamos juntos e eles reclamaram de tudo. Então pensei se não haveria algum jeito de viver da música que não envolvesse esse tipo de sofrimento. Eu passei a achar mais interessante estudar a música do que tentar fazer música como profissão. Além disso, eu tinha vários parentes que faziam música, e o sobrenome seria algo complicado. Enfim, parti para uma outra maneira de trabalhar com a música. A Antropologia da Música seria a maneira. Mas, para isso, eu teria de ser bom antropólogo. Então, eu me aprimorei para ser um bom antropólogo, eu estudei antropologia de verdade. Embora tenha tocado em festas e com amigos, a maior parte do tempo estava estudando antropologia pra valer.

Quero acabar falando um pouco sobre pós-graduação. É muito difícil ser aluno de pós-graduação. Eu tive muita sorte de ter bolsa o tempo todo - trabalhei muito e adorei. Realmente me diverti em meus anos de pós-graduação. Embora pareça que a vida é muito difícil, que são muito pobres, que não há tempo para ler e pesquisar, você tem muito mais 
Entrevista. Por que canta Anthony Seeger?

coisas para fazer depois de deixar de ser aluno. Nunca mais vai ter tanto tempo para pesquisa e leitura. Vocês que estão nessa fase aproveitem, vocês que já saíram, lamento muito. Mas, se Deus quiser, vocês conseguem uma posição como a que eu consegui no Museu Nacional, com ótimos colegas e alunos desafiantes.

Apesar de tudo, sem o banjo e minha mulher, a vida teria sido muito diferente. Em quase todos as oportunidades que tive em minha carreira o banjo teve um papel. Um bom exemplo foi minha entrada no Museu Nacional, muito facilitada pelo gosto que as pessoas têm pela música. No Smithsonian a mesma coisa. E hoje sou responsável por um grupo de alunos que tocam música de Bluegrass e stringband. Nunca me pensei como um dos mais inteligentes entre os antropólogos, mas sou um dos poucos que tocam banjo. 